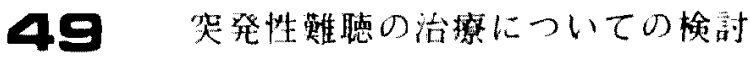

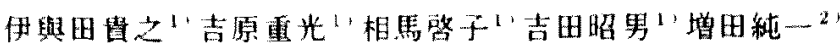

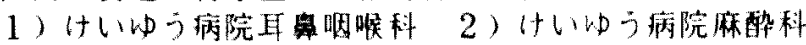

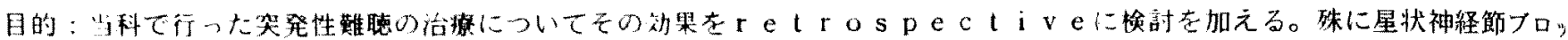

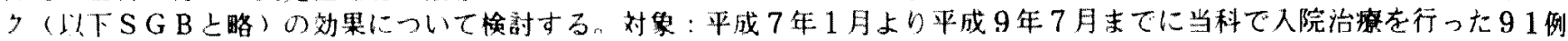

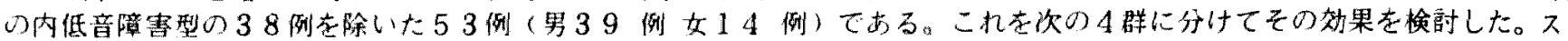

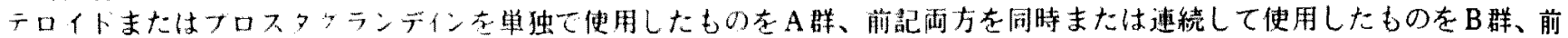

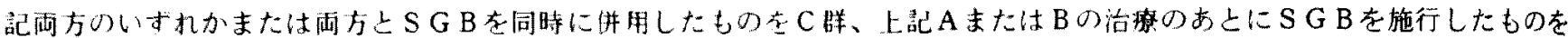

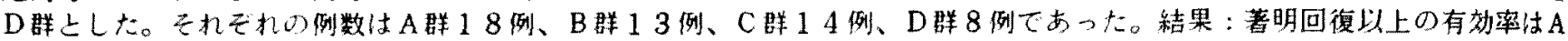

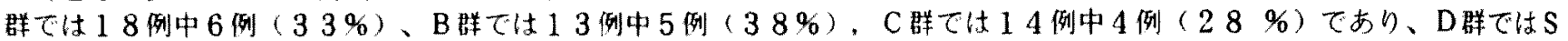

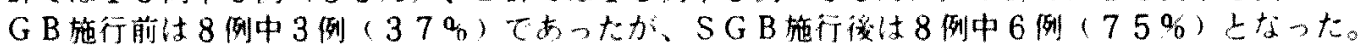

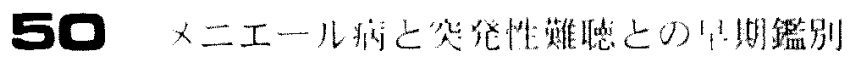

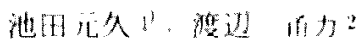

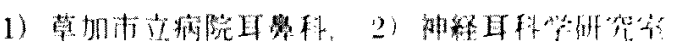

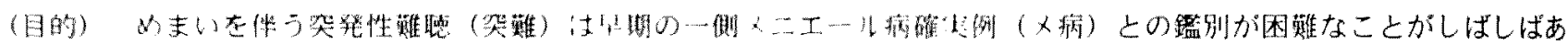

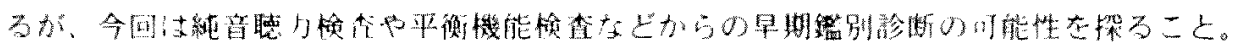

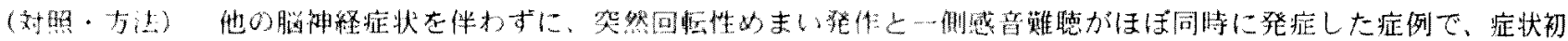

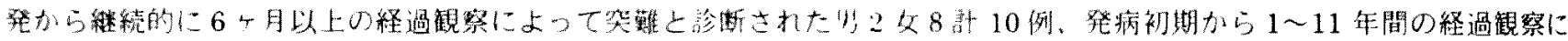

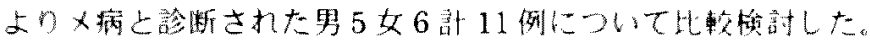

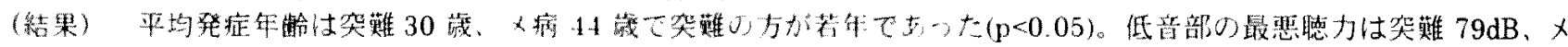

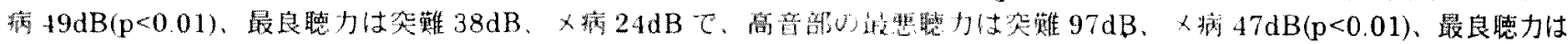

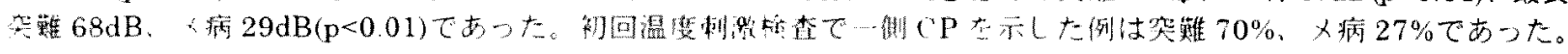

51 癸発性難聴は2つある(2) 一理論からのアプローチー

秦地秀佮、小川茂娃、䀳本 健

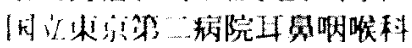

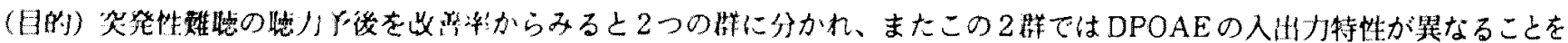

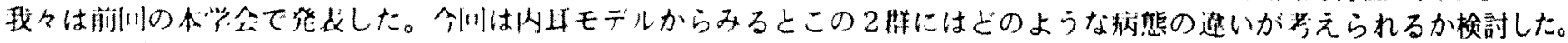

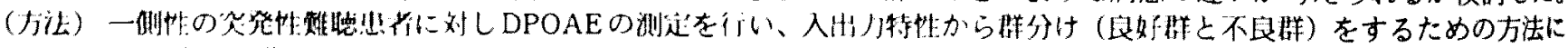

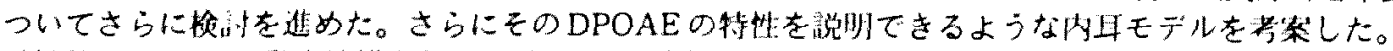

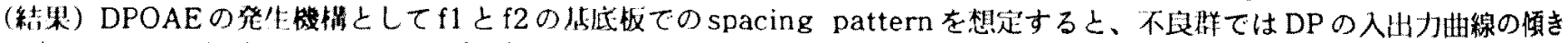
は大で、これは队且モデルでは外们モ緗胞のactiveな晁き（gain factor）を低下させたときに相当した。良好群ではDPの入

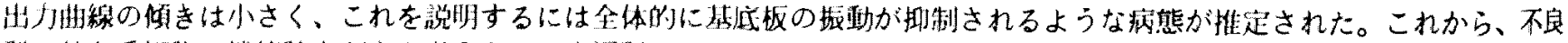

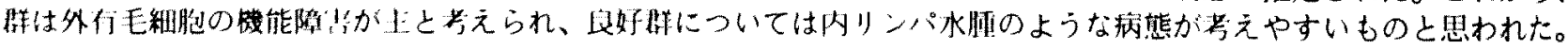

\title{
52 全国調査からみた乫発性難聴の推移
}

\section{中島 抻、藤彰英 名古屋大学耳咽喉科}

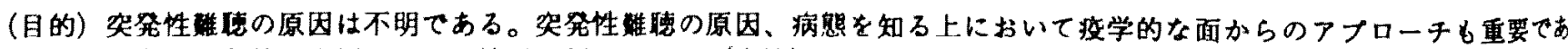
り、今回、全国の多数の症例をしとに检討を行った。 （方法）厚生省特定疾患調查研究班は、1972年、1987年、

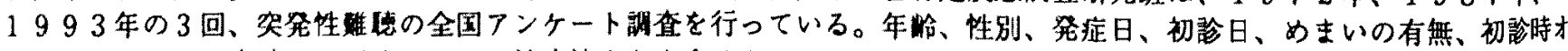
ージオグラム、固定時オーシオグラム、治捇法などを含めたアンケート䊅果は、名古屋大学に保管されている。今回、これら

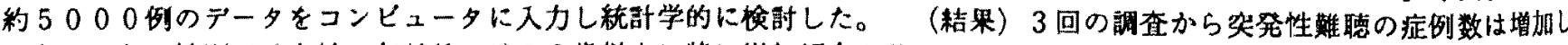

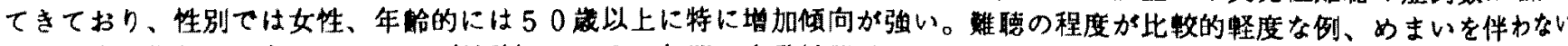

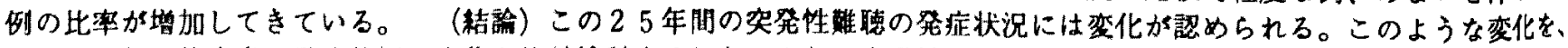

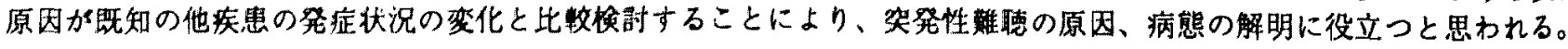

